\title{
Length-weight and Length-length Relationships of Farmed Catla catla during Winter Season from Muzaffargarh, Pakistan
}

\author{
Muhammad Khalid ${ }^{1,2}$, Samrah Masud ${ }^{2}$, Zara Naeem², Muhammad Munir Shahid ${ }^{3}$, Ammar Danyal \\ Naeem $^{2}$, Abir Ishtiaq ${ }^{2}$ and Muhammad Naeem ${ }^{2 *}$
}

${ }^{1}$ Department of Zoology, Govt. Emerson College, Multan, Pakistan; ${ }^{2}$ Institute of Pure and Applied Biology, Bahauddin Zakariya University, Multan; ${ }^{3}$ Planning and Development Division, Pakistan Agricultural Research Council, Islamabad, Pakistan.

\begin{abstract}
To study length-weight relationship (LWR) and length-length relationships (LLRs) of farmed Catla catla, thirty fish specimens were collected from a fish farm located at Muzaffargarh, Pakistan during January, 2019. Total length (TL), standard length (SL), fork length (FL) and body weight was taken of each fish specimen. Mean TL and body weight (W) of studied fish specimens of $C$. catla was found $49.14 \pm 1.58$ $\mathrm{cm}$ and $1775.29 \pm 191.18 \mathrm{~g}$, respectively. Results of regression analyses revealed highly significant $(\mathrm{P}<0.001)$ correlation for LWR and LLRs in farmed $C$. catla. Value of exponent $b$ was found 3.23 in LWR of farmed $C$. catla indicating positive allometric pattern of growth in C. catla. While, in LLRs, b-value was observed 1.00 or close to 1.00, indicating isometric pattern of growth in SL and FL with an increase in TL for the studied fish species. Mean condition factor value was found $1.49 \pm 0.04$ in the present work. Results of this work will be useful for fishery biologists and fisheries management.

Received | May 09, 2020; Accepted | July 27, 2020; Published | August 15, 2020

*Correspondence | Muhammad Naeem, Institute of Pure and Applied Biology, Bahauddin Zakariya University, Multan, Pakistan; Email: dr_ naeembzu@yahoo.com

Citation | Khalid, M., S. Masud, Z. Naeem, M.M. Shahid, A.D. Naeem, A. Ishtiaq and M. Naeem. 2020. Length-weight and length-length relationships of farmed Catla catla during winter season from Muzaffargarh, Pakistan. Sarhad Journal of Agriculture, 36(3): $924-928$.

DOI | http://dx.doi.org/10.17582/journal.sja/2020/36.3.924.928

Keywords | Carp, Length-weight relationship, Length-length relationship, Growth pattern, Fish farming
\end{abstract}

\section{Introduction}

$\mathrm{F}$ ish is a crucial nutritional constituent due to its high protein level. Fish body weight and total length are two valuable empirical measures in population calculation and commonly, in the studies of stock assessment and ecosystem biology (Jellyman et al., 2013). Fish weight can be assessed from total length whether the length-weight relationships (LWRs) are already documented for the studying fish species (Froese et al., 2011).

Length-weight relationships (LWRs) provide useful information for fishery management for both applied and basic purposes (Xiong et al., 2018). LWRs are frequently demonstrated with linear regressions by using logarithm to predictor and response variables. The significance of predicting LWRs in fish has been highlighted by different workers. It offers data about the habitat conditions, fish morphological characteristics, fish condition and fatness, life history, general health, growth pattern and fish age structure (Froese, 2006; Ogle, 2016). Moreover, it also allows fishery scientists to estimate weight of fish when it was difficult due to technical and field limitations and to simulate fish population dynamics and modeling food webs (Hilborn and Walters, 2001; Jellyman et al., 2013). Today it is indispensable to build fisheries management on solid stock assessment of the fisheries resources and therefore, basic data on biology and 
stock size of key species are urgently needed (Chen et al., 2020).

LWR might show variation over seasons (De Giosa et al., 2014). It is claimed that slope value (b) and growth pattern can differ during different time intervals demonstrating the gonads stages, condition of appetite, and fullness of stomach, as $b$-value is influenced by numerous abiotic and biotic factors (Zaher et al., 2015).

Furthermore, length-length relationships (LLRs) are important for fisheries management and for population growth relative studies (Moutopoulos and Stergiou, 2002). Condition factor $(\mathrm{K})$ is another significant biometric tool that is derived from LWRs (LeCren, 1951). K-value defines the deviance of mean weight of fish in a population for measurement of appropriateness of water environment for fish growth (Mensah, 2015).

The aim of the present study was to assess LWR, LLRs and condition factor of a major carp, Catla catla during winter season from farming system of Muzaffargarh, Pakistan.

\section{Materials and Methods}

A total of 30 fish specimens of a major carp, Catla catla were collected by using drag net from Punjab Fish Farm (Latitude: $30.320432^{\circ} \mathrm{N}$, Longitude: $71.361564^{\circ} \mathrm{E}$ ) located near Muzaffargarh, southern Punjab, Pakistan. Individual body weight $(\mathrm{W}, \mathrm{g})$ of C. catla was recorded to the nearest 0.01 gram. Total length (TL, cm), standard length (SL, $\mathrm{cm}$ ) and fork length $(\mathrm{FL}, \mathrm{cm})$ were measured to the nearest 0.1 centimeter.

The mathematical formula of the correlation between fish TL and $\mathrm{W}$ can be designated by power function. The length-weight relationship (LWR) was performed using the formula $W=a T L^{b}$. Data were also transformed into $\log$ arithm: $\log W=\log a+b \log$ $T L$ where $a$ is constant, and $b$ is slope of the linear regression that sets the allometric pattern of growth (Froese, 2006).

Moreover, length-length relationships (LLRs) were calculated by the technique of least squares to fit a simple linear regression model by taking the equations; $S L=a+b T L, F L=a+b T L$ and $S L=a+b$
$F L$. The 95\% confidence interval (CI) was determined for parameters " $a$ " and " $b$ " (Froese, 2006). In addition, condition factor $(\mathrm{K})$ was assessed by using formula, $K$ $=W / T L^{3} \times 100$.

\section{Results and Discussion}

Total, standard and fork lengths of Catla catla in this study were ranged 46.10-51.50, 37.50-42.00 and $40.00-45.50 \mathrm{~cm}$, with mean values $49.14 \pm 1.58$, $40.13 \pm 1.39$ and $43.19 \pm 1.47 \mathrm{~cm}$, respectively. While, body weight of $C$. catla was ranged 1500.00- 2121.38 $\mathrm{g}$ with mean value $1775.29 \pm 191.18 \mathrm{~g}$.

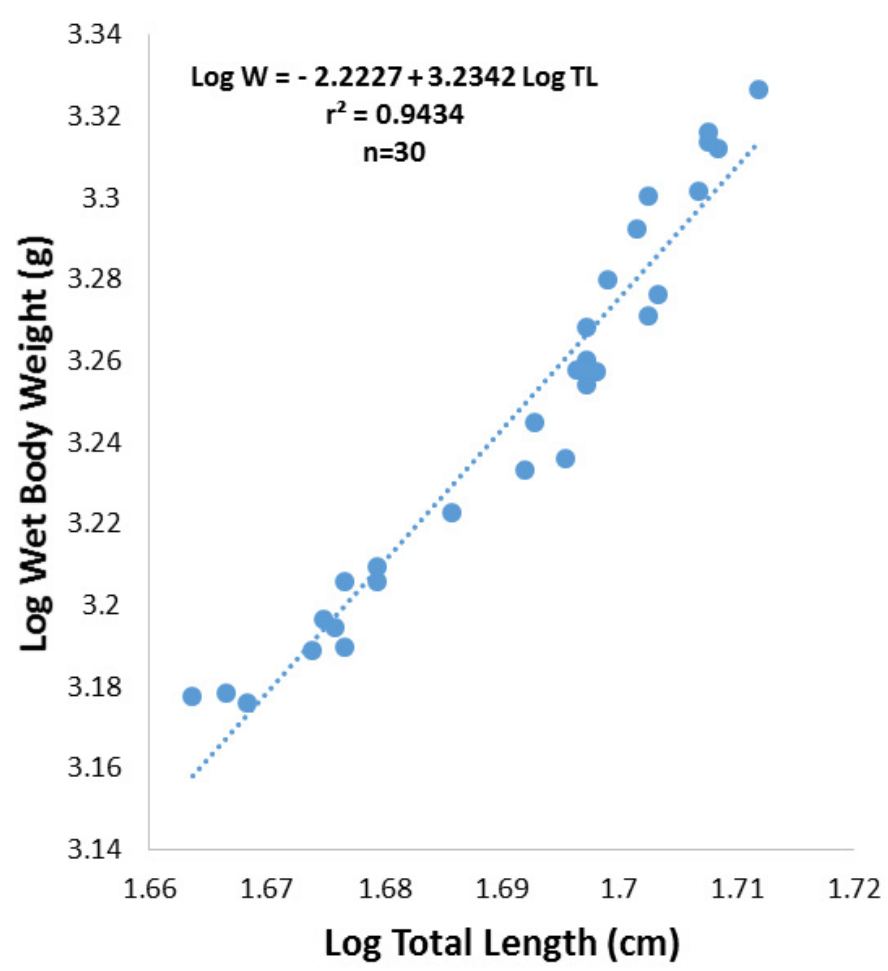

Figure 1: Length-weight relationship for log-transformed data of farmed Catla catla.

The relation between TL and $\mathrm{W}$ is exponential taking the general equation $Y=a X^{b}$, or $W=a T L^{b}$. When the data were converted to $\log$ form and plotted, a linear correlation was achieved (Figure 1). Log-transformed regression equation for the present study is as follows:

$$
\log W=-2.2227+3.2342 \log T L
$$

Length-weight relationship (LWR) was found highly significant with the coefficient of determination $\left(r^{2}\right)$ value 0.934 for Catla catla. Slope (b) value in this relationship was found 3.23 during winter season.

Detailed statistics on the length-length relationships (LLRs) for Catla catla collected from Muzaffargarh, 
Pakistan, are presented in Table 1, providing estimates for the equation parameters " $a$ " and " $b$ " along with the respective $95 \%$ confidence intervals and the coefficient of determination. In LLRs, all regressions were also highly significant $(\mathrm{P}<0.001)$, with the coefficient of determination $\left(r^{2}\right)$ ranging from 0.855 to 0.928 . Value of coefficient $b$ in these relationships was remained between 0.97 to 1.00 . Whereas, condition factor value was ranged from 1.41 to 1.56 , with a mean $1.49 \pm 0.04$.

Table 1: Regression parameters and associated statistics for length-length relationships of farmed Catla catla during winter season.

\section{a $\quad b \quad 95 \%$ CI of a $\quad 95 \%$ CI of b $r^{2}$}

$\mathrm{SL}=a+b \mathrm{TL}-0.08261 .00-0.3513$ to $0.1862 \quad 0.84$ to 1.160 .855

$\mathrm{FL}=a+b \mathrm{TL} \quad 0.0009 \quad 0.97-0.2874$ to $0.2892 \quad 0.80$ to 1.140 .828

$\mathrm{SL}=a+b \mathrm{FL} \quad 0.0038 \quad 0.98-0.1681$ to $0.1757 \quad 0.87$ to $1.08 \quad 0.928$

a: intercept; b: slope; Cl: confidence intervals; $r^{2}$ : coefficient of determination.

The high coefficient of determination values achieved in the calculation of LWR and LLRs in the present study reduced ambiguity (Nallathambi et al., 2020) and indicated a good quality of the prediction and small dispersion of the data (Correia et al., 2018) for linear regression in the observed fish specimens of Catla catla.

In the present work, value of parameter " $b$ " in the LWR remained 3.23, hence falls within the normal range i.e. 2.50-3.50 (Froese, 2006; Hanif et al., 2017). If specific gravity of a fish persist same and holds unchanged shape throughout life, growth pattern is denoted as isometrically and value of " $b$ " would be equal to 3.0 (Wootton, 1990). However, in the present study, $b>3$, indicated positive allometric pattern of growth in Catla catla that means large fish samples have grown more in weight than in length and robustness of large-sized specimens; or large samples were in good nutritional environments at sampling time (Froese, 2006). The results of the present study are in agreement with the study of Singh and Lakhwinder (2015), who have also reported $b$-value 3.20 for C. catla, and with the results of Hanif et al. (2020) who have documented this value 3.21 in a cyprinid fish species (Glossogobius aureus) indicating positive allometric growth pattern. On the other hand, Kartha and Rao (1990) and Ishtiaq and Naeem (2016) have documented isometric growth in C. catla, representing large samples have the same condition and shape as small samples. The detected variation could be clarified by various factors including number of samples, size, gonadal development, temperature (Macieira et al., 2008), season (Yeasmin et al., 2015), sex (Naeem et al., 2010) and feed availability (Ishtiaq and Naeem, 2016; Iqbal and Naeem, 2018).

Value of exponent $b$ in LLRs for $C$. catla, remained 1.00 or very close to 1.00 representing that standard length (SL) and fork length (FL) is growing isometrically in relation to total length of $C$. catla in this study. This indicates that SL and FL is increasing with the same proportion with an increase in TL of the fish. Similarly, SL also showed isometric pattern of growth with an increase in FL for farmed $C$. catla. Additionally, it can be inferred from the mean condition factor value that fish is in good condition as overall fitness for fish species is assumed when condition factor $(\mathrm{K})$ value is equal or close to 1 .

\section{Conclusions and Recommendations}

The high value of coefficient of determination $\left(r^{2}\right)$ for LWRs and LLRs in the present study represented small dispersion and good predictive power of the data. Moreover, parameter $b>3.0$ (positive allometic pattern of growth) in the estimates of LWR for farmed Catla catla during winter season, is the indication of highly nourished adult specimens.

\section{Acknowledgements}

The authors are grateful to the fish farmer of Punjab Fish Farm, Mr. Kamran Maqsood, for providing fish samples for data collection.

\section{Novelty Statement}

This study provides baseline information on the LWR, LLRs and condition factor of farmed Catla catla from Muzaffargarh, Pakistan. Furthermore, results achieved from this work will be beneficial to fishery biologists for future management of this species in culture conditions and to employ adequate estimations for specific geographic areas.

\section{Author's Contribution}

MK conducted the experiment and lab work, collected data and wrote the manuscript. MK conducted the experiment and lab work, collected data and wrote the manuscript. MK conducted the experiment and 
lab work, collected data and wrote the manuscript. MMS helped in data analysis and manuscript writing. ADN collected fish samples, assisted in lab work and data collection. AI analysed the data and helped in manuscript writing. MN supervised the research work, made available the necessary circumstances for the completion of experiment and assisted in the manuscript writing.

\section{Conflict of interest}

The authors have declared no conflict of interest.

\section{References}

Chen, F., H. Zhang, Z. Fang, A. Guo, R. Jiang, W. Zhu and Y. Zhou. 2020. Length-weight relationships for 15 fish species in the East China Sea mainly captured by the commercial fishery and subelemented by survey samples. J. Appl. Ichthyol., 36(4): 536-538. https://doi. org/10.1111/jai.14048

Correia, E.,J.P. Granadeiro, A. Regalla and P. Catry, 2018. Length weight relationship of fish species from the Bijagós Archipelago, Guinea-Bissau. J. Appl. Ichthyol., 34(1): 177-179. https://doi. org/10.1111/jai.13522

De Giosa, M., P. Czerniejewski and A. Rybczyk. 2014. Seasonal changes in condition factor and weight-length relationship of invasive Carassius gibelio (Bloch, 1782) from Leszczynskie Lakeland, Poland. Adv. Zool., Article ID 678763. https://doi.org/10.1155/2014/678763

Froese, R, A.C. Tsikliras and K.I. Stergiou. 2011. Editorial note on weight-length relations of fishes. Acta Ichthyol. Piscat., 41(4): 261-263. https://doi.org/10.3750/AIP2011.41.4.01

Froese, R., 2006. Cube law, condition factor and weight length relationship: history, meta-analysis and recommendations. J. Appl. Ichthyol., 22: 241-253. https://doi. org/10.1111/j.1439-0426.2006.00805.x

Hanif, M.A., M.A.B. Siddik, M.R. Chaklader, H.D. Pham and R. Kleindienst. 2017. Lengthweight relationships of three catfish species from a tributary of the Dhaleshwari River, Bangladesh. J. Appl. Ichthyol., 33(6): 12611262. https://doi.org/10.1111/jai.13448

Hanif, M.A., M.A.B. Siddik and M.M. Ali. 2020. Length-weight relationships of seven cyprinid fish species from the Kaptai Lake, Bangladesh. J. Appl. Ichthyol., 36(2): 261-264. https://doi. org/10.1111/jai.14016

Hilborn, R. and C.J. Walters. 2001. Quantitative fisheries stock assessment: Choice, dynamics, and uncertainty. $2^{\text {nd }}$ Ed. New York, NY: Chapman and Hall.

Iqbal, M.J. and M. Naeem. 2018. Study of external morphometric variants and length-weight relationship of Labeo rohita (Hamilton-1822) fed with varying protein levels. Sarhad J. Agric., 34(4): 749-759. https://doi.org/10.17582/ journal.sja/2018/34.4.749.759

Ishtiaq, A. and M. Naeem. 2016. Length-weight relationships and condition factor for farmed Catla catla (Hamilton, 1822) from southern Punjab, Pakistan. Punjab Univ. J. Zool., 31(2): 209-214.

Jellyman, P.G., D.J. Booker, S.K. Crow, M.L. Bonnett and D.J. Jellyman. 2013. Does one size fit all? An evaluation of length-weight relationships for New Zealand's freshwater fish species. N.Z. J. Mar. Freshwater Res., 47(4): 450-468. https://doi.org/10.1080/00288330.2 013.781510

Kartha, K.N. and K.S. Rao. 1990. Length weight and length maximum girth relationship C. catla (Ham.) in commercial landing of Gandhi sagar reservoir. Fish Tech., 27: 155-156.

LeCren,E.D.,1951.The length-weight relationship and seasonal cycle in gonadweight and condition in the Perch (Perca fluviatilis). J. Anim. Ecol., 20: 201-219. https://doi.org/10.2307/1540

Macieira, R.M. and J.C. Joyeux. 2008. Lengthweight relationships for rockpool fishes in Brazil. J. Appl. Ichthyol., 25(3): 358-359. https://doi. org/10.1111/j.1439-0426.2008.01118.x

Mensah, S.A., 2015. Weight-length models and relative condition factors of nine freshwater fish species from the Yapei Stretch of the White Volta, Ghana. Elixir Appl. Zool., 79: 3042730431.

Moutopoulos, D.K. and K.I. Stergiou. 2002. Length-weight and length-length relationships of fish species from the Aegean Sea (Greece). J. Appl. Ichthyol., 18(3): 200-203. https://doi. org/10.1046/j.1439-0426.2002.00281.x

Naeem, M., A. Salam, Q. Gillani and A. Ishtiaq. 2010. Length-weight relationships of Notopterus notopterus and introduced Oreochromis niloticus from the Indus River, southern Punjab. Pak. J. Appl. Ichthyol., 26: 620. https://doi. org/10.1111/j.1439-0426.2010.01480.x 
Nallathambi, M., N. Jayakumar, U. Arumugam, P. Jayasimhan, S. Chandran and K. Paramasivam. 2020. Length-weight relationships of six tropical estuarine fish species from Pulicat lagoon, India. J. Appl. Ichthyol., 36: 125-127. https://doi.org/10.1111/jai.13983

Ogle, D.H., 2016. Introductory fisheries analyses with R (Vol. 32). Boca Raton, FL: CRC Press. https://doi.org/10.1201/b19232

Singh, B.O. and K. Lakhwinder. 2015. LengthWeight Relationship of Catla catla (HamiltonBuchanan) from Harike wetland (Ramsar Site), Punjab, India. Int. Res. J. Biol. Sci., 4(6): 44-47.

Wootton, R.J., 1990. Ecology of teleost fishes. Chapman and Hall, London. https://doi. org/10.1007/978-94-009-0829-1
Xiong, W., X.W. Zhu, D. Xie and C.H. Pan. 2018. Length-weight relationships of eight fish species from mangroves of Guangdong, China. J. Appl. Ichthyol., 33: 1240-1241. https://doi. org/10.1111/jai.13588

Yeasmin, F., Z.F. Ahmed, M.G. Ara, M.S. Mia M.K. and Fatema. 2015. Length-weight relationships and growth pattern of a danionin fish species Chela cachius (Hamilton, 1822) of a perennial lake in Bangladesh. Int. J. Nat. Soc. Sci., 2: 70-74.

Zaher, F.M., B.M.S. Rahman, A. Rahman, M.A. Alam and M.H. Pramanik. 2015. Lengthweight relationship and GSI of hilsa, Tenualosa ilisha (Hamilton, 1822) fishes in Meghna river, Bangladesh. Int. J. Nat. Soc. Sci., 2: 82-88. 